\title{
TEOLOGI DOA MARTIN LUTHER
}

\section{Charles Femmy Marunduri}

GRII Batam

\begin{abstract}
ABSTRAK: Teologi doa Luther merupakan salah satu teologi doa Kristen yang penting. Luther dalam teologi doanya menunjukkan hubungan yang erat antara teologi dan doa. Ia juga menerapkan pengertian-pengertian teologi doanya. Kehidupan dan pelayanannya memperlihatkan doa sebagai sarana utama kehendak Allah dikerjakan dalam hidupnya. Luther adalah seorang yang berdoa. Ia menyatakan alasan mengapa doa begitu penting dalam hidupnya dalam tulisantulisan teologisnya. Dengan melihat makna doa, motivasi doa, sikap doa, sasaran doa, cara berdoa, syarat-syarat doa, doa dan Allah Tritunggal, doa dan Anfechtungen, serta manfaat doa maka teologi doa Luther dapat disarikan dan disusun menjadi suatu teologi doa yang alkitabiah.
\end{abstract}

KATA KUNCI: Luther, doa, teologi, Anfechtungen.

ABSTRACT: Luther's theology of prayer is one of the important Christian theologies of prayer. In his theology, Luther showed a close relationship between theology and prayer. He put into practice the meanings of his theology of prayer. His living and ministry exhibited prayer as primary means through which the will of God was embodied in his life. Luther was a man of prayer. He declared the reason why prayer was so important in his life in his theological writings. Through the meaning of prayer, the motivation of prayer, the manner or attitude of prayer, the way of prayer, the requirements of prayer, prayer and The Trinity, prayer and Anfechtungen, as well the benefit of prayer, as of Luther theology of prayer can be summarized and arranged to be a biblical theology of prayer.

KEYWORDS: Luther, prayer, theology, Anfechtungen. 


\section{Pendahuluan}

Doa adalah suatu aspek kerohanian dalam kekristenan yang memiliki kedudukan yang penting, karena merupakan tanda seseorang mengenal Allah. Pengenalan akan Allah merupakan dasar keselamatan seseorang (Yohanes 17:3). Pengertian doa demikian banyak digumulkan dan dituliskan oleh Martin Luther. Di dalam sejarah Luther merupakan salah seorang teolog penting yang memikirkan dan mengaplikasikan doa dalam hidupnya. Dalam tulisan-tulisan teologinya, Luther memperlihatkan hubungan yang erat antara doa dengan teologi. Baginya teologi tidak dapat dipisahkan dari doa. Tinjauan secara teologis akan memperlihatkan kekuatan, sekaligus juga kelemahan pandangan doa Luther, sehingga kontribusi pemikirannya ini dapat menjadi pijakan kehidupan Kristen.

Luther adalah seorang yang berdoa. Ia memakai waktu berjam-jam untuk berdoa sejak ia tinggal di dalam biara. ${ }^{1}$ Luther adalah orang yang bukan hanya mengajarkan tentang doa, namun juga meneladankannya dengan konsisten dalam hidupnya. ${ }^{2}$ Ia adalah seorang yang sangat sibuk, tetapi memiliki jam doa yang banyak. ${ }^{3}$ Salah satu kalimatnya yang terkenal tentang doa adalah "Hari ini saya harus menyediakan waktu lebih banyak untuk berdoa. Sebab banyak sekali yang harus saya lakukan."

\section{Teologi Doa Luther}

Luther tidak menuliskan satu karya teologis secara khusus dan sistematis, seperti Thomas Aquinas dengan Theological Summa, Philip Melanchthon dengan Loci Praecipui Theologici, atau Yohanes Calvin

\footnotetext{
1 James M, Kittelson, Luther The Reformer: The Story of The Man and His Career (Minneapolis: Fortress, 2003), 53.

2 Brian G. Najapfour, "Martin Luther on Prayer and Reformation," dalam Taking Hold of God, ed. Joel R. Beeke dan Brian G. Najapfour (Grand Rapids: Reformation Heritage Books, 2011), 24.

3 W. J. Kooiman, Martin Luther: Doktor dalam Kitab Suci, Reformator Gereja (Jakarta: BPK Gunung Mulia, 2011), 39-40.

4 Ibid., 40.
} 
dengan Institutes of the Christian Religion. ${ }^{5}$ Luther menuliskan pandangan-pandangan teologisnya di dalam banyak bentuk tulisan dan tersebar di dalam pembahasan-pembahasannya terhadap persoalanpersoalan yang khusus. ${ }^{6}$ Teologi doa Luther tidak ditulis dalam suatu karya tersendiri, melainkan tersebar di dalam tulisan-tulisannya yang membahas banyak hal. ${ }^{7}$

Dalam tulisan ini Penulis akan memaparkan teologi doa Luther secara sistematis untuk memperlihatkan konsep Luther tentang kedudukan dan peran doa dalam kehidupan orang percaya. Bagian ini akan menjelaskan mengenai makna doa, motivasi doa, sikap doa, sasaran doa, cara berdoa, syarat-syarat doa yang Benar, doa dan Allah Tritunggal, doa dan Anfechtungen, dan manfaat doa menurut Luther. Pembahasan ini bertujuan membentuk bangunan sistematika teologi doa Luther yang dapat menjadi tumpuan kehidupan Kristen, khususnya kehidupan doa.

\section{Makna Doa}

Pengertian atau makna doa yang benar diperlukan untuk mendasari pelaksanaannya yang tepat. Menurut teologi doa Luther setidaknya ada empat makna doa bagi kehidupan orang percaya, keempat makna doa ini ditunjukkan dalam hidup dan pelayanannya sebagai teolog, gembala, dan reformator.

Pertama, bagi Luther doa adalah percakapan dengan Allah atau komunikasi dengan Allah, ia menjelaskan, "to pray is simply to call upon God's holy name." 8 Robert Kolb dan Charles P. Arand menjelaskan pandangan Luther tersebut demikian,

\footnotetext{
5 Oswald Bayer, Martin Luther's Theology: A Contemporary Interpretation (Grand Rapids: Eerdmans, 2008), xv.

6 Ibid., xvi.

7 Robert Kolb, Martin Luther as Prophet, Teacher, and Hero (Grand Rapids: Baker, 1999), 171. Bdk. penjelasan Najapfour: It must be remembered that Luther was not a systematic theologian. While he had several works on prayer, he did not write a single book or section of a book that could be considered his comprehensive theology of prayer; rather it scattered throughout his writings. [Najapfour, Martin Luther on Prayer and Reformation, 7].

8 Martin Luther, The Book of Concord the confessions of the Evangelical Lutheran Church. ed. T.

G. Tappert (Philadelphia: Muihlenberg Press, 1959), 420.
} 
Prayer is the conversation of the dependent and trusting child, who is eager to voice both thanks and requests with the loving Father, who in turn is eager to hear from his children. ${ }^{9}$

Berbicara kepada Tuhan atau berdoa menurut Luther merupakan hak istimewa yang diberikan Allah kepada orang percaya, Luther mengatakan,

To speak to God means to pray; this is indeed a great glory that the high majesty of heaven should stoop to us poor worms and permit us to open our mouths to him . . . but it is still more glorious and more precious that he should speak to us and that we should hear him. ${ }^{10}$

Jadi bagi Luther dalam berdoa orang percaya bukan hanya memiliki hak istimewa berbicara kepada Allah yang mulia, tapi juga hal yang lebih mulia lagi adalah mendengarkan Allah yang mulia berbicara kepada orang percaya. Kesediaan Allah mendengarkan dan menjawab doa orang percaya merupakan anugerah yang benar-benar besar dan mulia bagi manusia yang hina.

Kedua, berdoa bagi Luther merupakan suatu tindakan menghormati nama Tuhan. Luther menemukan makna doa ini pada saat ia mempelajari hukum kedua ${ }^{11}$ dari Sepuluh Hukum Allah. Luther berpendapat bahwa hukum kedua yang melarang orang menyebut nama Tuhan dengan sembarang juga secara bersamaan merupakan hukum yang memerintahkan orang untuk menghormati nama Tuhan. ${ }^{12}$ Luther mengatakan demikian: "We are to fear and love God, so that we . . instead use the very name in every time of need to call on, pray to, praise, and give

\footnotetext{
9 Robert Kolp dan Charles P. Arand, The Genius of Luther's Theology: A Wittenberg Way of Thinking for the Contemporary Church (Grand Rapids: Baker Academic, 2008), 214.

10 Dikutip di dalam Deanna Marie Carr, "A Consideration of the Meaning of Prayer in the Life of Martin Luther," Concordia Theological Monthly 42, no. 10 (1971), 622.

11 Mengenai perbedaan urutan hukum Allah ini, berikut penjelasan Najapfour, “Unlike the Reformed, Lutherans consider the prohibitions against other gods and against worshiping idols to be one commandment, and they find two commandments under "Thou shalt not covet." Thus the Lutherans second commandment is the Reformed third commandment. [Najapfour, Martin Luther on Prayer and Reformation,10].

12 Timothy G. Wengert, Martin Luther Catechisms: Forming the Faith (Minneapolis: Fortress, 2009), 75 .
} 
thanks to God."13 Pemahaman Luther ini dibangun di atas penafsiran bahwa menurutnya makna suatu teks Alkitab yang tersurat menyatakan juga makna sebaliknya, atau yang bertentangan dengan teks tersebut secara tersirat. ${ }^{14}$ Wengert menjelaskan pemikiran Luther tersebut,

If a text forbids something, it means God is promoting the opposite. If a text promises something, it also means it is excluding something harmful. Regarding the explanations to the commandments . . . this meant for Luther that negative commandments had a positive side and vice versa. ${ }^{15}$

Berdasarkan uraian di atas, maka dapat disimpulkan bahwa orang yang tidak berdoa berarti tidak menghormati nama Tuhan, karena doa adalah wujud penghormatan kepada nama Tuhan. Perintah kedua bukan hanya melarang orang menyebut nama Tuhan dengan sembarangan, tetapi sekaligus memerintah orang untuk menghormati nama Tuhan.

Ketiga, doa merupakan kewajiban atau tanggung jawab. Luther secara tegas menyatakannya demikian, "it is our duty to pray." 16 Ia mendasarkan pengertian ini juga kepada perintah Allah, "Prayer is obligatory because 'God has commanded it." 17 Dengan demikian, tidak berdoa merupakan dosa yang serius dan memiliki konsekuensi hukuman yang sama beratnya dengan hukuman karena berzinah, membunuh, atau menyembah berhala. ${ }^{18}$

Prayer, therefore, is as strictly and solemnly commanded as all the other commandments (such as having no other God, not killing, not stealing, etc.) lest anyone thinks it makes no difference whether I pray or not, as vulgar people do who say in their delusion: "Why should I pray? Who knows whether God pays attention to my prayer or wants to hear it? ${ }^{19}$

\footnotetext{
13 Martin Luther, The Book of Concord: The confessions of the Evangelical Lutheran Church. ed. Robert Kolb, Timothy J. Wengert, dan Charles P. Arand (Minneapolis: Fortress, 2000), 352.

14 Ibid., 75-76.

15 Ibid., 76.

16 Luther, The Book of Concord. ed. Tappert, 420.

17 Ibid.

18 Najapfour, Martin Luther on Prayer and Reformation, 8.

19 Luther, The Book of Concord. ed. Kolb, Wengert, dan Arand, 441.
} 
Karena itu, Luther menulis, "From the fact that prayer is so urgently commanded, we ought to conclude that we should by no means despise our prayers, but rather prize them highly." 20

Berpijak pada uraian di atas, maka pengertian doa sebagai berseru kepada Allah dengan doa sebagai menghormati nama Allah dan sebagai kewajiban dapat menimbulkan kesalahpahaman terhadap pandangan Luther tersebut. Kesalahpahaman dapat berupa dugaan bahwa Luther tidak mementingkan ketulusan, dan kesungguhan hati orang yang berdoa. Oleh karena itu Luther juga menegaskan bahwa doa tidak dapat dipisahkan dari kebutuhan manusia. Wengert menulis, "Luther linked need with prayer."21 Dalam hal ini, tampak Luther menunjukkan alasan, mengapa doa adalah suatu keharusan sekaligus kesungguhan hati. Oleh karena itu, doa merupakan kebutuhan orang percaya.

Luther bahkan memandang doa sebagai nafas kehidupan orang percaya. Ia mengatakan, "To be a Christian without prayer is no more possible than to be alive without breathing." 22 Pengertian ini menunjukkan bahwa doa merupakan kebutuhan pokok orang percaya. Doa sebagai kebutuhan orang percaya merangkum ketiga makna tentang doa sebelumnya sebagai kebutuhan orang percaya. Melalui doa orang percaya belajar menyadari bahwa kebutuhannya yang hakiki adalah untuk berseru kepada nama Tuhan; untuk menghormati nama Tuhan; dan untuk bertanggung jawab kepada Tuhan.

Keempat, doa merupakan pekerjaan yang terberat. Doa adalah sesuatu yang mustahil dilakukan oleh manusia secara alamiah. Manusia harus mengalami anugerah keselamatan untuk mampu berdoa. Luther mengatakan bahwa doa hanya dapat dikerjakan oleh orang percaya saja, "for before we are Christians and believe, we know neither for what nor how we are to pray. "23 Orang yang tidak percaya tidak dapat berdoa sama sekali. ${ }^{24}$

\footnotetext{
20 Luther, The Book of Concord. ed. Tappert, 422.

21 Wengert, Martin Luther Catechisms, 76.

22 http://www.prayingthegospels.com/martin-luther-quotes-2/short-quotes-martin-luther/ Diakses 25 Mei 2016.

23 Ewald M. Plass, ed., What Luther Says: A practical In-Home Anthology for The Active
} 
Doa orang-orang yang tidak percaya bukanlah doa, melainkan cemoohan kepada Allah, karena menurut Luther, doa mereka tidak berdasarkan anugerah di dalam Kristus, tetapi berdasarkan apa yang dianggap oleh mereka sebagai jasa diri dan kelayakan diri. ${ }^{25}$

Dengan demikian, bagi Luther, doa adalah,

the hardest work of all . . . a labor above all labors, since he who prays must wage a mighty warfare against the doubt and murmuring excited by the faintheartedness and unworthiness we feel within us. ${ }^{26}$

Kedagingan atau natur berdosa adalah penghalang utama doa, sedangkan selama di dunia orang percaya masih memiliki kedagingan atau natur berdosa. Luther memandang bahwa, "the Christian is a person who is simul justus et peccator (simultaneously righteous and sinful)." 27 Realitas ini menyebabkan doa merupakan suatu perjuangan yang berat.

Alasan lain Luther memandang doa sebagai pekerjaan yang terberat, karena ia tahu betapa berat tuntutan rohaninya untuk berdoa. ${ }^{28}$ Menurutnya, doa merupakan pekerjaan yang lebih berat dari pada berkhotbah dan pekerjaan-pekerjaan lain di dalam gereja. Luther berargumen demikian,

When we are preaching the Word, we are more passive than active; God is speaking through us, and our teaching is His work. This is the reason why [prayer] is also very rare. ${ }^{29}$

Khotbah atau mengajar merupakan sarana yang Allah gunakan untuk menyampaikan kehendak-Nya, sehingga sebenarnya Allah yang berbicara dan orang yang berkhotbah atau mengajar lebih pasif daripada

Christian (St. Louis: Concordia, 1959), 1077. Dikutip di dalam Najapfour, Martin Luther on Prayer and Reformation, 9.

24 Ibid.

25 Ibid.

26 Heiler, Prayer: A Study in the History and Psychology of Religion, 263.

27 Martin Luther, Luther's Works, Vol. 26 : Lectures on Galatians, 1535. ed. Jaroslav Pelikan, H.

C. Oswald, dan H. T. Lehmann (Saint Louis : Concordia, 1963), 232.

28 Najapfour, Martin Luther on Prayer and Reformation, 9.

29 Ibid. 
aktif. Sedangkan doa menuntut orang yang berdoa untuk mencurahkan seluruh perhatiannya dalam iman kepada Allah, karena ia menentang kedagingan atau natur berdosanya yang selalu berusaha menghalanginya berdoa. Dengan demikian doa lebih menuntut secara rohani daripada berkhotbah. Bahkan khotbah akan menjadi berkuasa dan berdampak setelah pengkhotbah bergumul dalam doa.

Untuk memahami makna doa ini secara lebih mendalam perlu dibahas motivasi dan tujuan berdoa. Luther memberikan motivasimotivasi doa yang khas kekristenan, sehingga memberikan keteguhan kepada orang percaya dalam berdoa.

\section{Motivasi Doa}

Berdasarkan pengertian atau makna doa di atas, teologi doa Luther juga menjelaskan motivasi-motivasi apa saja yang dapat memberikan kepada orang percaya dorongan dan keyakinan untuk berdoa. Motivasi doa yang pertama adalah perintah Allah. Bagi Luther motif utama di dalam doa adalah perintah Allah. Ia mengatakan: "On this commandment, on which all the saints base their prayer, I too, base mine." 30

Hal ini berkaitan dengan makna doa sebagai kewajiban atau tanggung jawab dan makna doa sebagai penghormatan kepada nama Allah. Perintah Allah memberikan motivasi yang besar untuk berdoa, karena perintah Allah menegaskan kebenaran dan kehendak Allah sebagai satu-satunya yang berhak dan berkuasa atas hidup manusia. Perintah Allah menjadikan penolakan terhadap doa sebagai dosa. Oleh karena itu orang percaya tidak memiliki alasan untuk tidak berdoa, sebagaimana Wengert mengamati pandangan Luther bahwa, "The commandment, ... also eliminated all the old creature's excuses for not praying." 31

30 Luther, The Book of Concord. ed. Tappert, 422.
31 Wengert, Martin Luther Catechisms, 77. 
Luther memandang bahwa perintah Allah sebagai dorongan atau motivasi doa, menekankan tanggung jawab. ${ }^{32}$ Dorongan doa demikian tidak akan memberikan kemuliaan kepada orang percaya, tetapi kepada Allah. Bukan karena kelayakan atau jasa orang percaya, maka ia berdoa, apa lagi jika doanya didengar, melainkan karena perintah Allah atau kehendak Allah.

Kedua, motivasi doa adalah janji Allah. Janji Allah untuk menjawab doa merupakan motivasi yang penting untuk berdoa. Dalam khotbahnya berdasarkan Yohanes 16:23-30, Luther menegaskan motif janji Allah terhadap doa demikian: "In this Gospel we have a promise and Christ do not only promise, but He even swears that our prayers shall be heard; but through himself as mediator and high priest."33 Dengan kata lain, janji Allah yang bahkan didasarkan pada diri Yesus Kristus, tentunya merupakan motivasi yang kuat untuk berdoa. Luther juga menggambarkan bagaimana ia memiliki keyakinan dalam meminta kepada Allah dan bagaimana janji Allah itu sendiri menggerakkan seseorang untuk berdoa:

Up until now, prayer has preserved the church. Thus we must continue to pray. That is why Christ says, "Ask, seek, knock!" First we are to ask. Now, as soon as we start asking, God sneaks away somewhere and doesn't want to hear and to be found. So, a person has to start searching, that is, keep on praying. When a person seeks for him, God shuts himself up in a closet. If someone wants to get in, that person has to start knocking. Of course, if someone knocks only once or twice, God ignores it. Finally, when the knocking gets to be too much, God opens the door and says, "Whatever do you want?" "Lord, I want this or that." Then God says, "All right! Go ahead and have it." Thus, you have to wake God up. I'm of the opinion that there are still a lot of godly people here [who pray this way], as sure as there are also a lot of evil jerks [who do not]. Thus, the verse 'Ask ...' implies nothing less than: "Ask, shout, cry, search, knock, bang!" Moreover, a person has to keep it up without stopping. ${ }^{34}$

\footnotetext{
32 Luther, "The Large Catechism," 420. Bdk. Mark Rogers, "Deliver Us from the Evil One: Martin Luther on Prayer," Themelios 34.3 (2009): 338.

33 John Nicholas Lenker, ed., The Complete Sermons of Martin Luther: Volume 2.1-2 (Grand Rapids: Baker, 2000), 167.

34 WA TR 5:123 (no. 5392). Dikutip dalam Wengert, Martin Luther Catechisms, 81.
} 
Motivasi doa yang berdasarkan perintah dan janji Allah menolong orang percaya untuk memiliki keberanian datang ke hadapan takhta Allah dan memohon kasih karunia, yaitu pertolongan-Nya, karena bukan kelayakannya yang mendasari doanya. Dengan demikian orang percaya tidak perlu merasa harus menjadi baik dahulu, atau merasa tenang dahulu, atau merasa ingin berdoa dahulu, baru berdoa. Orang percaya harus selalu berdoa, karena doa adalah perintah dan janji Allah.

Berikutnya, satu-satunya sarana yang berperan menghubungkan doa dengan perintah dan janji Allah adalah iman. ${ }^{35}$ Luther menulis,

Without faith in the promise, there is then, neither courage nor desire to pray, but mere uncertain delusion and melancholy spirit; there is, therefore, no hearing of prayers, and both prayer and labor are lost. ${ }^{36}$

Demikian juga, menurut Luther, "we should pray that we may have peace through faith." 37

Doa yang berdasarkan kehendak Allah (firman Allah) memberikan keyakinan bahwa Allah pasti mendengarkan dan menjawab doa. Namun demikian gagasan ini tidak berarti bahwa Allah selalu menjawab doa-doa orang percaya sesuai harapan mereka, melainkan bahwa Allah menjawab doa sesuai kehendak-Nya. Luther mengatakan,

We have this advantage: that our prayer is always heard. Even if it is not heard according to our will, nevertheless it is heard according to the will of God, which is better than our will. If I do not know that my prayer would be heard, it would be the devil praying in my place. ${ }^{38}$

Doa yang dijawab Allah sesuai dengan kehendak-Nya, justru adalah kebaikan yang sebenarnya bagi orang percaya sebagaimana kesimpulan Luther di atas. Orang percaya mengikatkan hidupnya kepada Allah melalui doa, karena Allah satu-satunya sumber kehidupan

\footnotetext{
35 Lenker, ed., The Complete Sermons of Martin Luther, 169.

36 Ibid., 168.

37 Ibid., 167.

38 WA TR 2:628-629 (no. 2742a dan 2742b). Dikutip dalam Timothy G. Wengert, Martin

Luther Catechisms: Forming the Faith (Minneapolis: Fortress, 2009), 71.
} 
dan segala kebaikan.

Dua motivasi doa ini, yaitu perintah dan janji Allah memperlihatkan konsistensi Luther dalam mendasarkan teologi doanya pada doktrin pembenaran oleh iman. Kedua motivasi doa tersebut tidak dapat dimiliki manusia tanpa iman, karena iman saja yang menjadikan kebenaran firman Allah teraplikasi dalam hidup orang percaya. Dengan demikian doa yang dimotivasi perintah dan janji Allah tentu merupakan doa yang berdasarkan iman kepada firman Allah. Orang percaya beroleh "keberanian menghampiri takhta kasih karunia," (Ibrani 4:16) bukan karena kelayakan atau jasanya, melainkan karena kasih karunia Allah di dalam Yesus Kristus melalui iman saja. Luther mengatakan:

Ach, what a great thing the prayer of the godly is! How powerful it is before God, that a poor soul should talk with God and not be frightened in his presence, but instead know that God smiles at him in a friendly manner because of Jesus Christ. The conscience must not run away on account of its unworthiness or be overwhelmed with doubts or let itself be frightened. ${ }^{39}$

Perintah dan janji Allah adalah firman Allah, sehingga doa yang dimotivasi kedua aspek firman Allah ini adalah doa yang sesuai dengan kehendak Allah, dan juga merupakan doa yang mengungkapkan kebutuhan orang percaya yang sebenarnya.

\section{Sikap Doa}

Dalam berbagai pemabahasannya tentang doa, Luther menekankan iman dan kesungguhan hati. Sedangkan sikap atau posisi tubuh pada saat berdoa bukan merupakan hal yang memerlukan perhatian atau pengaturan khusus. Dalam nasehatnya kepada pemangkas rambutnya, Luther mengatakan,

It is of little importance whether you stand, kneel, or prostrate yourself; for the posture of the body are neither forbidden nor commanded as necessary. The same applies to other things: raising the head and the eyes

39 WA TR 3:447 (no. 3605). Dikutip dalam Wengert, Martin Luther Catechisms,72. 
heavenward, folding the hands, striking the breast. ${ }^{40}$

\section{Sasaran Doa}

Sasaran doa adalah diri Allah sendiri yang dinyatakan dalam tiga petisi pertama dalam Doa Bapa Kami. Dalam doa ini jelas, kekudusan nama Allah, kehadiran kerajaan Allah, dan terwujudnya kehendak Allah merupakan manifestasi dari dipenuhinya kebutuhan orang percaya sebagaimana terungkap dalam empat petisi terakhir. Pemenuhan terhadap kebutuhan fisik (kecukupan makanan sehari); relasional (pengampunan); dan rohani (dihindarkan dan dilindungi dari pencobaan dan si jahat) adalah demi kemuliaan Allah dalam tiga petisi pertama.

Pengertian di atas tersebut memperlihatkan bahwa kebutuhan manusia yang utama adalah kemuliaan Allah, dan segala kebutuhan bagi kehidupannya bergantung pada kemuliaan Allah itu dinyatakan. Dalam hal ini tampak jelas kaitan erat antara kemuliaan Allah dan kesejahteraan hidup manusia. Sasaran doa demikian sekali lagi menegaskan posisi Allah dan posisi manusia sebagaimana diperlihatkan oleh doktrin pembenaran oleh iman, yaitu Allah adalah Allah pencipta sumber segala kebaikan (segala sesuatu) dan manusia adalah makhluk ciptaan yang bergantung secara total kepada-Nya. ${ }^{41}$

\section{Cara Berdoa}

Dalam mendiskusikan tentang cara berdoa, Luther membahasnya berdasarkan latar belakang praktek-praktek kesalehan Roma Katolik pada abad pertengahan. Luther menentang cara berdoa pada masanya yang diwajibkan oleh Paus. Baginya, cara-cara tersebut hanyalah ocehanocehan dan penyia-nyiaan kata-kata, karena hanya dilafalkan tanpa pengertian. Luther menggambarkan doa-doa yang diwajibkan Paus pada

\footnotetext{
$40 \quad$ Ewald M. Plass, ed., What Luther Says: A practical In-Home Anthology for The Active Christian (St. Louis: Concordia, 1959), 1087. Dikutip di dalam Najapfour, Martin Luther on Prayer and Reformation, 16.

41 Diskusi doktrin pembenaran oleh iman yang ditemukan Luther ini dibahas dengan baik oleh Paul Althaus dalam bukunya The Theology of Martin Luther (Philadelphia: Fortress, 1966), 118-129.
} 
masanya demikian:

The pope commands a threefold manner of praying. The material prayer, in which a person recites words he does not understand, as the nuns do with the psalter. This was merely a prayer to satisfy the pope. The other, the formal prayer, in which one does understand the words. The third, the effectual prayer, the prayer of devotion and meaning. The third is the right essence and quality of prayer. But on this there is no insistence, but only on the material prayer, that the words were recited and read, as a parrot talks. From this sprang a desolate ocean full of hours of prayer, the howling and shouting in convents and monasteries in which the psalms and lections were sung and read without spirit, in manner that a person neither understood nor retained either words or sentences of meaning. ${ }^{42}$

Berdasarkan latar belakang teologi doa abad pertengahan ini maka dalam tulisan-tulisannya nampak Luther mengusulkan dua cara berdoa yang dipandangnya benar. Pertama, spontanitas dalam doa. Doa yang sejati yang berasal dari hati dan dimengerti oleh si pendoa. Dalam hal ini doa bersifat spontan. Dalam tafsirannya terhadap Roma 12:7-16 ia menekankan doa dari dalam hati, "prayer must come from the heart spontaneously, without any prepared and prescribed words." 43

Doa yang spontan bukan saja harus keluar dari dasar hati, tetapi juga dapat dipahami. Dalam hal ini orang percaya harus memakai katakatanya sendiri dalam doa dan mengerti apa dan mengapa ia berdoa. Luther mengungkapkannya demikian,

Our prayer must have few words, but be great and profound in content and meaning. The fewer the words, the better the prayer; the more words, the poorer the prayer. Few words and richness of meaning is Christian; many words and lack of meaning is pagan. ${ }^{44}$

42 Leonhard Ludwig, "Luther, Man of Prayer," dalam Interpreting Luther's Legacy, ed. Fred W. Meuser dan Stanley D. Schneider (Minneapolis: Augsburg, 1969), 164. Dikutip di dalam Najapfour, Martin Luther on Prayer and Reformation, 12-13.

43 Najapfour, Martin Luther on Prayer and Reformation, 13.

44 Martin Luther, An Exposition of The Lord's Prayer for Simple Laymen. Luther's Works, vol. 42: Devotional Writings I. terj. H. Bertram dan ed. oleh J. J. Pelikan, H. C. Oswald dan H. T.

Lehmann (Philadelphia: Fortress, 1969), 19. 
Kedua, doa yang dituliskan atau disiapkan. Luther sebenarnya tidak menentang doa yang disiapkan dalam sebuah naskah, karena dalam beberapa tulisannya hal itu nampak jelas. Dalam katekismus kecilnya, Luther memberikan nasehat kepada orang tua untuk mengajarkan anak-anak mereka dan anggota keluarga lain untuk mengucapkan suatu bentuk doa yang ia cantumkan di sana. Ia memberikan instruksinya demikian:

When the children and the whole household gather at the table, they should reverently fold their hands and say: "The eyes of all look to Thee, O Lord, and Thou givest them their food in due season. Thou openest Thy hand; Thou satisfies the desire of every living thing." Then the Lord's Prayer should be said, and afterwards this prayer: "Lord God, heavenly Father, bless us, and these Thy gifts which of Thy bountiful goodness Thou hast bestowed on us, through Jesus Christ our Lord. Amen!" 45

\section{Syarat-Syarat Doa yang Benar}

Dalam teologinya, Luther juga membahas syarat-syarat doa yang benar. Terdapat tiga syarat doa yang benar. Luther membahas syaratsyarat tersebut berdasarkan khotbahnya dari Yohanes 16:23-30. Syarat yang pertama adalah permintaan dalam doa harus jelas. Luther menulis, "one must name definitely something that he brings to God or for which he prays; as for strong faith, for love, for peace, and for the comfort of his neighbor." 46 Syarat ini penting, karena menunjukkan keseriusan orang percaya berdoa.

Syarat kedua adalah doa yang dipanjatkan harus benar-benar diinginkan. Luther mengatakan, "that we must desire, or wish that the petition be granted, which nothing but asking." 47 Hal yang benar-benar diinginkan tentunya adalah kebutuhan orang percaya. Kebutuhan ini harus benar-benar disadari dan dirasakan, karena jika tidak demikian, maka sebagaimana komentar Wengert terhadap nasehat Luther:

\footnotetext{
45 Najapfour, Martin Luther on Prayer and Reformation, 14.

46 John Nicholas Lenker, ed., The Complete Sermons of Martin Luther: Vol. 2. 1-2 (Grand Rapids: Baker, 2000), 170.

47 Ibid.
} 
If prayer is not asking and begging God out of true human needs, it is simply howling and growling, unwilling or unable to ask "even for a droplet wine." Worse yet, it is one more form of works righteousness, so twisted that it never even occurs to the worker to ask God for anything. ${ }^{48}$

Kebutuhan yang benar-benar disadari yang menghasilkan kesungguhan dalam berdoa. Luther menggambarkan kebutuhan manusia demikian,

But where there is to be true prayer, there must be utter earnestness. We must feel our need, the distress and drives and impels us to cry out. Then prayer will come spontaneously, as it should, and no one will need to be taught how to prepare for it or how to create the proper devotion. ${ }^{49}$

Dengan demikian orang percaya harus menyebutkan dengan jelas kebutuhan yang disampaikannya kepada Allah dalam doa. ${ }^{50}$

Syarat ketiga, doa harus di dalam nama Yesus. ${ }^{51}$ Syarat ini mendasari segala pengabulan doa orang percaya, karena Kristus merupakan satu-satunya pengantara orang percaya dengan Allah. Luther menjelaskannya demikian:

This is nothing more than that we come before God in the faith of Christ and comfort ourselves with the sure confidence that he is our Mediator, through whom all things are given to us, without whom we merit nothing but wrath and disgrace. ${ }^{52}$

Ketiga syarat ini menunjukkan doa yang sesuai dengan kehendak Allah. Doa yang demikian menyatakan bahwa orang percaya benarbenar menginginkan kehendak Allah terlaksana. Dalam doa Bapa Kami, kehendak Allah, yaitu Nama-Nya dikuduskan, Kerajaan-Nya datang, dan Kehendak-Nya jadi diberikan-Nya kepada orang percaya melalui memenuhi kebutuhan fisik orang percaya (makanan kami yang secukupnya), kebutuhan relasi (pengampunan), kebutuhan akan

\footnotetext{
Wengert, Martin Luther Catechisms, 84.

Kolb, Wengert, dan Arand, The Book of Concord, 444.

Lenker, ed., The Complete Sermons of Martin Luther, 170.

Ibid., 171.

Ibid.
} 
keamanan jasmani dan rohani (tidak jatuh ke dalam pencobaan dan terlepas dari segala yang jahat). Doa Bapa Kami ini menunjukkan dengan jelas hubungan yang erat antara kehendak Allah dan kebutuhan orang percaya, sehingga orang percaya dapat mengatakan bahwa kehendak Allah adalah kebutuhannya (Yohanes 4:34).

\section{Doa dan Allah Tritunggal}

Luther juga menegaskan bahwa teologi doanya ortodoks dengan menonjolkan dimensi Allah Tritunggal dari doa. ${ }^{53}$ Doa berkaitan erat dengan kebenaran tentang keberadaan Allah sebagai Allah Tritunggal.

Pertama, Doa kepada Allah Bapa. Dalam penjelasan doa Bapa Kami, Luther menulis:

The best way to begin or introduce the prayer is to know how to address, honor, and treat the person to whom we submit our petition, and how to conduct ourselves in his presence, so that he will be gracious towards us and willing to listen to us. ${ }^{54}$

Mengenal masing-masing pribadi dalam Tritunggal menolong menguatkan keyakinan orang percaya. Dalam mengomentari penyebutan nama Allah Bapa dalam doa, Luther menulis:

Now, of all names there is none that gains us more favor with God than that of 'Father.' This is indeed a friendly, sweet, intimate, and warmhearted word. To speak the words 'Lord' or 'God' or 'Judge' would not be nearly as gracious and comforting to us. The name 'Father' is of our nature and is sweet by nature. That is why the most pleasing to God, and why no other name moves him so stongly to hear. ${ }^{55}$

Doa kepada Allah Bapa dengan menyebut nama "Bapa," menurut Luther benar-benar menggerakkan hati Allah. Luther menjelaskan demikian,

\footnotetext{
53 Najapfour, Martin Luther on Prayer and Reformation, 20.

54 Luther, An Exposition of The Lord's Prayer, LW 42, 22.

55 Ibid.
} 
With this name, we likewise confess that we are children of God, which again stirs his heart mightily; for there is no lovelier sound than that of a child speaking to his father. ${ }^{56}$

Kesadaran akan pribadi Allah Bapa dan menyebutkan nama-Nya sedemikian penting, sehingga menurut Luther, sekalipun orang percaya hanya mampu mengucapkan "Bapa," dengan sepenuh hati dalam pergumulannya, ia akan mendapatkan pertolongan Allah. ${ }^{57}$ Sebagaimana sudah dijelaskan sebelumnya, Luther mengatakan bahwa berseru kepada nama Tuhan sudah merupakan doa. Bahkan jika orang percaya hanya mengatakan "Bapa kami," ia sebenarnya telah berdoa.

Doa kepada Allah sebagai Bapa juga mencegah orang percaya dari menaikkan doa yang mementingkan diri sendiri atau egois. Seruan doa kepada Bapa, berarti mengakui satu tubuh Kristus atau komunitas orang percaya. Luther menyatakannya demikian:

Jesus does not want anyone to pray only for himself, but for all mankind. He does not teach us to say 'My Father,' but 'Our Father.' Since prayer is a spiritual good which is held in common by all, we dare not deprive anyone of it, not even our enemies. For since God is the Father of us all, he also wants us to be like brothers to each other, who love each other dearly and who pray for one another as each does for himself. ${ }^{58}$

Kedua, doa di dalam nama Allah Anak. Yesus Kristus adalah pengantara satu-satunya orang berdosa yang percaya dengan Allah, maka doa sebagai komunikasi dengan Allah harus berdasarkan atau dalam nama Yesus. Dalam hal prinsip Reformasi bahwa hanya Kristus saja atau solus Christus diaplikasi. Luther mengatakan, "that apart from Christ no one is able to pray a single letter that is worth anything before God and acceptable to him."59 Nama Yesus adalah jaminan yang kokoh untuk doadoa orang percaya. Orang percaya tidak bersandar pada diri mereka

\footnotetext{
Ibid.

Luther, An Exposition of The Lord's Prayer, LW 42, 23.

Ibid., 26.

9 Plass, ed., What Luther Says, 1077.
} 
sendiri, tetapi pada nama Yesus, satu-satunya yang memastikan perkenanan Allah kepada doa-doa mereka. ${ }^{60}$

Ketiga, doa dengan pertolongan Allah Roh Kudus. Doa ditujukan kepada Allah Bapa di dalam nama Allah Anak, dan dengan pertolongan Allah Roh Kudus. Pertolongan Roh Kudus adalah satu-satunya yang menyebabkan doa orang percaya diterima oleh Allah. Dengan demikian doa orang yang tidak percaya tidak mungkin diterima oleh Allah. ${ }^{61}$

Pandangan Luther ini menegaskan bahwa hanya orang yang benar-benar telah dilahirkan kembali oleh Roh Kudus yang dapat benarbenar berdoa. ${ }^{62}$ Roh Kuduslah yang menggerakkan hati orang percaya untuk berdoa. Namun, sekalipun doa disampaikan kepada Bapa, di dalam nama Anak, dan oleh pertolongan Roh Kudus, doa dapat juga ditujukan kepada Anak atau Roh Kudus pula. Luther menjelaskannya demikian:

When you call upon Jesus Christ and say: O my dear Lord, God, my creator, and Father, Jesus Christ, Thou one eternal God, you need not worry that the Father and Holy Spirit will be angry on this account. They know that no matter which Person you call upon, you call upon all three Persons and upon the One God at the same time. For you cannot call upon one Person without calling upon the others, because the one, undivided devine Essence exists in all and in each Person. Conversely, you cannot deny any Person in particular without denying all three and the One God in His entirety, as 1 John 2:23 says: 'Whosoever denieth the Son, the same hath not the Father.' ${ }^{\prime 6}$

\section{Doa dan Anfechtungen}

Anfechtungen merupakan peperangan rohani (spiritual conflict), sehingga orang percaya sering kali mengalami kesulitan untuk berdoa dalam saat-saat demikian. Anfechtungen merupakan suatu situasi yang menunjukkan pergumulan iman dan hati nurani yang berat. Menurut Luther, dalam keadaan demikian Allah tampaknya diam, tidak hadir,

\footnotetext{
60 Najapfour, Martin Luther on Prayer and Reformation, 22.

61 Ibid.

62 Ibid., 23.

63 Plass, ed., What Luther Says, 1082.
} 
atau bahkan sepertinya Ia justru menjadi lawan orang percaya. Carr menggambarkan pengalaman dan kesimpulan Luther tersebut Anfechtungen demikian:

Luther lived out his life in the tension between the hidden and the experienced God, longing for the gracious presence but always threatened by the impending absence. It is the considered opinion of reputable scholars that the remote and terrible God was often more real to the reformer than was the beloved, benign, and merciful Lord. By his own admission, he suffered Anfechtungen, that is, temptations, doubts, and anxiety of heart. For this reason, prayer was not easy for Luther. ${ }^{64}$

Allah dalam Anfechtungen terasa lebih nyata bagi Luther dari pada Allah yang penuh kasih, ramah, dan murah hati.65 Dalam keadaan ini, doa benar-benar sulit dilakukan. Anfechtungen menunjukkan bahwa orang percaya berada di dalam situasi yang gawat atau bahkan putus asa. Kittelson menguraikan mengenai tantangan berat Anfechtungen bagi Luther, demikian:

Anfechtungen was what Luther latter called this grinding sense of being utterly lost. By it he intended the idea of swarming attacks of doubt that could convince people that God's love was not for them. Latter he considered this sense of being irredeemably evil to be the work of Satan, who sought to make a Cristian's sins, doubts, and anxieties too much even for the grace of God. At such moments just the rustling of dried leaves in forest sounded like legions of hell coming to seize one's soul. ${ }^{66}$

Bertolak dari pengertian Anfechtungen seperti di atas dapat disimpulkan bahwa jika seorang percaya berada di dalam keadaan demikian, ia sebenarnya sedang berada di dalam peperangan yang sengit. Ia sedang diuji oleh Allah, tetapi juga pada saat yang sama sedang dicobai oleh Iblis.

Dalam keadaan demikian orang percaya sukar untuk berdoa, padahal doa yang menyebabkan Anfechtungen. Ia dikelilingi oleh permusuhan dalam Anfechtungen. Scaer membahas pengalaman Luther

64 Carr, "A Consideration of the Meaning of Prayer in the Life of Martin Luther," 621.

65 Ibid.

66 Kittelson, Luther the Reformer, 56. 
tersebut demikian:

Right during the act of praying Luther himself was afflicted by sin, Satan, and his own conscience. Prayer was the occasion for Anfechtungen. As he prayed, Luther was afflicted with the thought that was not hearing his prayer and that God was becoming angry with him. . . So troubled was Luther with the thought of his own sinfulness and his lack of worthiness to pray that all he could do was cry out, "Help, dear Lord." 67

Orang percaya akan melihat ketidaklayakkannya dan ketidakberdayaannya dalam Anfechtungen. Namun justru orang percaya benar-benar membutuhkan doa saat ia berada dalam Anfechtungen.

Doa memang adalah kebutuhan setiap saat orang percaya, sebagaimana udara (oksigen) untuk bernafas. Namun demikian sebagaimana oksigen akan sangat dibutuhkan seseorang yang sedang dalam keadaan sakit tertentu, maka begitu pula dengan doa sangat dibutuhkan dalam Anfechtungen, karena saat Anfechtungen merupakan saat serangan gencar Setan. Rogers menjelaskan pemahaman Luther bahwa serangan utama Setan adalah,

[to] tempt Christians to doubt their salvation and attacks their conscience by reminding them of their great sinfulness. Luther teaches people to pray that God would help them withstand the accusations and assaults of the accuser. ${ }^{68}$

Karena itu, Luther mendorong orang percaya untuk selalu siap menghadapi peperangan rohani:

We who would be Christians must surely expect to have the devil with all his angels and the world as our enemies and must expect that they will inflict every possible misfortune and grief upon us. For where God's Word is preached, accepted, or believed, and bears fruit, there the holy and precious cross will also not be far behind. ${ }^{69}$

67 Scaer, "Luther on Prayer," 306.

68 Rogers, "Deliver Us from the Evil One: Martin Luther on Prayer," 341.

69 Luther, The Book of Concord, 448. 
Pandangan-pandangan Luther di atas tentang Anfechtungen menunjukkan bahwa Anfechtungen justru merupakan motivasi yang kuat untuk berdoa, dan bahkan untuk tetap berdoa dalam keadaan apapun. Scaer menyimpulkan, "Rather than seeing Anfechtungen as a hindrace to prayer, the Anfechtungen are themselves invitations to pray. "70

\section{Manfaat Doa}

Doa tidak meniadakan kerja. Doa tidak meniadakan persiapan untuk melakukan pekerjaan atau proyek apapun saja. Dalam pandangan Luther, segala sesuatu atau segala ciptaan adalah "topeng" Allah, yang melaluinya Ia menyembunyikan diri-Nya, namun tetap melaksanakan karya providensia-Nya. ${ }^{71}$

Luther berpendapat bahwa terdapat keterlibatan yang erat antara Allah dan dunia ini. Pendapat Luther ini sama dengan pandangan Calvin tentang providensia Allah. Menurut Luther aktivitas manusia dalam bentuk apapun saja tidak terlepas dari keterlibatan Allah. Apapun saja peristiwa yang terjadi, dapat terjadi, karena Allah terlibat. Dengan demikian pekerjaan manusia merupakan pekerjaan Allah juga. Wingren menulis,

Normally man works together with God by using with all his power and understanding the things which God has created. It happens in home, field, workshop, and government. ${ }^{72}$

Manusia yang menjalankan panggilan adalah manusia yang menjalankan kehidupannya. Orang yang memakai atau memanfaatkan ciptaan Allah di sekelilingnya dengan segenap kekuatan dan pemahamannya akan menghasilkan apa yang berguna bagi hidupnya. Semua ini terjadi di dalam segala aspek hidup.

Orang yang tidak menggunakan semua yang sudah Allah sediakan untuk melaksanakan kehidupannya, mencobai Allah. Dengan

\footnotetext{
Scaer, "Luther on Prayer," 306.

Gustaf Wingren, Luther on Vocation (Eugene: Wipf \& Stock, 2004), 138

Ibid., 184-85.
} 
demikian kemalasan merupakan tindakan mencobai Allah. Dalam hal ini, berdoa meminta pertolongan Tuhan sama artinya dengan meminta ijin untuk malas. Doa setiap waktu atau tanpa henti tidak dimaksudkan untuk menghentikan pekerjaan orang.

Doa yang berkuasa adalah doa yang dipanjatkan oleh orang yang mengerjakan pekerjaannya dengan rajin. Wingren mengungkapkan pandangan Luther dalam hal ini demikian:

He who has not done what he can with creation's gifts does not have the firm faith that can confront God and pray for more. In answer to such lazy petitions God only points to the gifts already given in creation and says, 'Thou shalt labor.'” ..., "that there are times when all human ways are blocked. In a special sense this is the time for prayer. ${ }^{73}$

Uraian di atas menunjukkan bahwa pengertian doa dan kerja di atas sepertinya mengarahkan kesungguh-sungguhan berdoa hanya pada waktu seseorang merasakan kebutuhan yang besar atas sesuatu. Kesalahan pengertian memang dapat terjadi, karena itu Wingren melanjutkan apa yang dimaksudkan Luther, demikian, "To be sure, Luther pleads for regular devotions, for morning and evening prayers, and not only for prayer in manifest need. "74

Manfaat doa bagi panggilan, yaitu dalam hal doa menjadikan orang percaya setia kepada panggilannya. Kesetiaan terhadap panggilannya ini sebaliknya juga makin menguatkan doa-doanya. Dengan demikian orang percaya dapat mengalami apa yang ia imani.

\section{Tinjauan Kristis Terhadap Teologi Doa Luther}

Terdapat beberapa elemen dalam teologi doa Luther yang perlu ditinjau secara kritis. Pertama, kondisi doa yang hanya diliputi oleh apa yang disebut Luther Anfechtungen. Bahkan, Luther menekankan bahwa Anfechtungen ini memberikan motivasi yang kuat untuk berdoa. Namun pandangan Luther ini kurang tepat, karena Alkitab menyatakan segi-segi

$\begin{array}{ll}73 & \text { Ibid., } 185 . \\ 74 & \text { Ibid. }\end{array}$ 
lain yang berlimpah sebagai motivasi di dalam doa, termasuk keadaan dan motivasi doa yang tidak semata-mata karena kesulitan, pencobaan, dan serangan-serangan Iblis (Anfechtungen) dalam hidup orang percaya di dunia ini. Alkitab menunjukkan bahwa doa tidak berhenti di dunia ini saja, melainkan akan terus berlangsung dalam kehidupan kekal di Surga (Wahyu 6:9-11), sehingga sulit untuk menerima bahwa Anfechtungen berperan besar dalam memotivasi doa orang percaya, karena di Surga tentu tidak ada lagi Anfechtungen, tetapi doa tetap ada.

Anfechtungen juga tidak tepat menjadi motivasi terkuat untuk doa untuk beberapa alasan berikut: (1) jika Anfechtungen dianggap memberikan dorongan yang besar bagi doa, maka hal ini berarti membesarkan kesulitan, penderitaan, pencobaan, atau Iblis sendiri lebih dari pada Allah. Alkitab tidak memberikan tempat bagi kemungkinan ini. (2) Jika menjadikan Anfechtungen sebagai dorongan yang memberikan keseriusan yang besar terhadap perlunya berdoa, maka sama juga dengan menganggap bahwa kebesaran atau kemuliaan Allah kurang memiliki keseriusan dibandingkan Anfechtungen. Hal ini tentu bertentangan dengan pengajaran Alkitab yang jelas bahwa kemuliaan dan kebesaran Allah merupakan alasan paling serius mengapa orang percaya harus mencari-Nya dalam doa (Mazmur 63:1-3, 5). Andrew Murray dengan tepat memperlihatkan hal ini dalam eksposisinya terhadap Yohanes 14:12, 13, demikian,

That the Father may be glorified in the Son. For this reason, Jesus on His throne in glory will do all we ask in His name. Every answer to prayer He gives will have this as its object: when there is no prospect of the Father being glorified, He will not answer. ${ }^{75}$

(3) Penekanan Luther pada Anfechtungen sebagai salah satu motivasi doa yang kuat dapat menyebabkan orang percaya salah memahami maksudnya, sehingga mengakibatkan munculnya minat yang ekstrim, seperti minat terhadap pengusiran setan. Minat ini dapat

75 Andrew Murray, The Believer School of Prayer, 115. 
menyebabkan orang percaya disesatkan oleh pandangan-pandangan takhyul tentang roh-roh jahat, sehingga menyimpangkan iman kepada Allah dalam Kristus menjadi iman kepada metode-metode manusia. Kebesaran Allah dapat menjadi kabur, karena fokus yang lebih ditujukan justru kepada iblis dan roh-roh jahatnya.

Tinjauan yang kedua adalah berkenaan dengan pandangan Luther bahwa doa harus dipanjatkan dengan keyakinan. Pandangannya ini tentu saja benar, karena sesuai dengan Firman Tuhan. Namun ia kemudian menyimpulkan bahwa doa dapat mengubah rencana Allah. Hal ini ditunjukkannya dalam komentarnya mengenai pembebasan Lot dari Sodom dan Gomora. Kolb menyimpulkan komentar Luther tersebut demikian, "This prayer from a faithful believer caused God to change his mind regarding the destruction of Zoar." 76 Jadi menurut Luther, doa dengan keyakinan yang kuat dapat mengubah rencana Allah.

Hal ini jelas bertentangan dengan pengajaran Alkitab tentang kemahatahuan dan kemahakuasaan Allah. Demikian juga hal ini menunjukkan ketidak-konsistenan Luther dalam ajarannya, karena di tempat lain ia menegaskan bahwa kehendak Allah tetap terjadi sekalipun terdapat kejahatan dan dosa di dunia ini. ${ }^{77}$ Penegasannya ini jelas menunjukkan bahwa Allah tidak dapat diubah oleh doa. Namun ini tidak berarti bahwa Allah tidak dapat tergerak oleh doa-doa umat-Nya. ${ }^{78}$

\section{Kesimpulan}

Teologi doa Luther merupakan salah satu teologi doa Kristen yang sangat penting dalam meningkatkan kehidupan Kristen dalam diri orang percaya. Teologi doa Luther memperlihatkan hubungan erat antara teologi dengan doa. Demikian juga, sifat teologi doa Luther sederhana

\footnotetext{
76 Robert Kolb, Luther and the Stories of God (Grand Rapids: Baker Academic, 2012), 139.

77 Martin Luther, Personal Prayer Book, Luther's works, vol. 43: Devotional Writings II. terj. Martin H. Bertram dan ed. Gustav K. Wiencke, J. J. Pelikan, H. C. Oswald dan H. T. Lehmann (Philadelphia: Fortress, 1968), 444.

78 Lih. D. A. Carson, chapter A Sovereign and Personal God dalam A Call to Spiritual Reformation: Priorities from Paul and His Prayers (Grand Rapids: Baker, 1997), 145-166.
} 
dan praktis yang tampak dalam pengertian-pengertian doa menurut Luther.

Beberapa manfaat teologi doa Luther tampak dalam kesimpulan berikut.

Pertama, doa sebagai tindakan dalam menghormati nama Tuhan memberikan keharusan doa yang mutlak ada di dalam kehidupan orang percaya. Seseorang yang mengaku percaya harus menunjukkan imannya itu dalam doa. Ia kini menjadikan Allah sebagai pusat dan tujuan hidupnya. Doa menjadi kegiatan utamanya, sehingga kehadiran Allah lebih dirasakan dan memberikan keberanian dan kedamaian dalam menghadapi berbagai kesulitan dalam hidup.

Kedua, doa merupakan pekerjaan yang terberat, karena orang yang berdoa dengan sungguh-sungguh sebenarnya harus menyangkal dirinya atau melawan dirinya (kedagingannya). Tanpa kehidupan doa, manusia berada dalam belenggu diri sendiri, dunia, dan Iblis, karena ia hidup bertumpu pada dirinya sendiri yang tidak saja terbatas, tetapi juga berdosa dalam segala aspeknya.

Ketiga, doa merupakan kewajiban atau tanggung jawab. Doa adalah sebuah kewajiban, karena doa merupakan perintah Allah. Doa merupakan kewajiban utama orang percaya yang harus dikerjakan dengan serius, jika ia ingin kehidupan rohaninya terpelihara dan bertumbuh. Sekalipun doa merupakan pekerjaan yang terberat dan kewajiban, namun demikian doa merupakan tempat pelarian atau persebunyian orang percaya di dalam Allah. Doa merupakan tindakan menjadikan Allah perlindungan yang memberikan damai sejahterah di tengah-tengah pergumulan hidup yang berat, sehingga orang percaya beroleh kekuatan atau kuasa untuk menanggung pergumulanpergumulan hidupnya.

Keempat, doa sebagai peperangan dalam Anfechtungen. Dunia, kedagingan, dan Iblis akan selalu melingkupi orang percaya selama hidupnya di dunia ini. Kenyataan ini sangat serius, karena itu orang percaya tidak boleh lengah, melainkan ia harus senantiasa waspada dan 
siap untuk berperang. Doa tidak boleh berhenti dalam hatinya, tetapi harus terus terwujud dalam seluruh perbuatannya. Sikap hati yang berdoa selalu menandakan kebergantungan orang percaya kepada Allah sekaligus juga perlindungan Allah kepadanya.

Ajaran Luther tentang doa juga mengedepankan tentang motivasi untuk berdoa. Motivasi doa yang utama adalah perintah dan janji Allah. Kedua hal ini memberikan motivasi yang kuat untuk berdoa sekaligus untuk mempelajari Firman Tuhan. Orang percaya harus berdoa, karena Allah memerintahkannya dan bahkan Ia juga menjanjikan jawaban untuk doa-doa mereka.

Sasaran doa juga merupakan hal yang penting. Doa ditujukan semata-mata kepada Allah Tritunggal, karena keselamatan dan kehidupan Kristen adalah karya Allah Tritunggal. Orang percaya berdoa kepada Allah Bapa dalam nama Allah Anak dan dengan pertolongan Allah Roh Kudus. Oleh karena doa orang percaya ditujukan kepada Allah Tritunggal, maka syaratnya yang utama adalah berdoa dengan iman. Kehidupan doa merupakan kehidupan iman. Orang percaya bekerja atau melakukan apapun saja harus di dalam iman, sehingga seluruh kehidupannya merupakan kehidupan yang menggenapi kehendak Allah.

Semua pembahasan teologi doa Luther menunjukkan pentingnya teologi doa ini dipelajari, dimengerti, dan diterapkan dalam kehidupan orang-orang percaya. Kenyataan Reformasi yang mengubah sejarah, baik sejarah gereja maupun umum menunjukkan pemikiran teologi Luther yang dikonfirmasikan oleh Allah sendiri. Sekalipun dalam teologinya juga ada hal-hal yang perlu dikritisi, tetapi dalam hal-hal yang esensial Luther benar-benar menyatakan ajaran Alkitab yang benar. 